\title{
"You've Never Seen this Kind of Poverty": Facing Class and Gender in Shoah Representations ${ }^{1}$
}

\author{
Marion Gerlind San Francisco State University
}

\begin{abstract}
Résumé
Dans la reconstruction du Holocauste (ou "Shoah") par les chercheurs et chercheuses, les vies des gens ordinaires-des vies plus appauvries et limitées que celles des individus de la classe moyenne et supérieure - ont pour la plupart du temps été négligées. Ce n'est que rarement qu'a été examinée la manière dont genre et classe entrent dans les rapports de mort et de survie. En intégrant des anlayses féministes avec des théories de classe, j'explore les différences entre les représentations des femmes juives des classes ouvrières et moyennes en terms d'oppression multiples. Les représentations littéraires contiennent souvent des partis pris puisqu' elles se fient, presque exclusivement, à des enquê tes sur les juifs citadins et de class moyenne. En alliant l'analyse textuelle avec des méthodes de l'histoire orale, j'ai fait des interviews enregistrés (en audio) avec des survivantes et j'ai enquêté sur les temoignages enregistrés en video ainsi que sur des récits à la troisième personne non-publiés; j'ai également examiné l'influence du statut socio-économique sur la vie quotidienne des juives polonaises et allemandes durant les années de l'EntreGuerre (1919-38) et de la Deuxième Guerre Mondiale. Je vise en premier lieu à recueillir les histoires de vie de survivantes marginalisées,en deuxième lieu à démontrer que la classe sociale doit être conceptuellement centrale à l'analyse du Holocauste et, finalement, à contribuer à un discours interdisciplinaire sur la classe et le genre.En interprétant des témoignages qui risquent d'être perdus et en dé-stigmatisant la pauvreté et le travail manuel, nous exposons les inégalités sociales et, ce faisant, pouvons donner de l'ampleur et de la profondeur à notre compréhension du Holocauste.
\end{abstract}

\begin{abstract}
In researchers' reconstructions of the Holocaust, also called the Shoah, the lives of ordinary people-lives more impoverished and constrained than those of middle- and upper-class individuals - have been largely overlooked. Rarely have the ways in which gender and class enter into accounts of death and survival been examined. Integrating feminist gender analyses with class theories, I explore differences between working- and middle-class Jewish women's representations in terms of multiple oppressions. Literary representations

\footnotetext{
${ }^{1}$ I thank all my interviewees for sharing their life stories with me. I wish to gratefully acknowledge the assistance of JB, Dr. Norma Smith, and Dr. Raymond Barglow for discussing drafts of this paper, and Dr. Sima Aprahamian for suggesting its submission. I also thank Dr. Sandra RollingsMagnusson and the three anonymous reviewers of Socialist Studies for their valuable feedback.
} 


\section{"You've Never Seen this Kind of Poverty": Facing Class and Gender in Shoah Representations}

often contain class biases because they rely, almost exclusively, on investigations of middle-class, and urban Jews. Combining textual analysis with oral history methods, I conducted audio-taped interviews with survivors, researched videotaped testimonies as well as unpublished third-person narratives and examined the influence of socioeconomic status on Polish- and German-Jewish women's everyday lives in the interwar years (191938) and during World War II. My goals are first, to record life histories of marginalized survivors, and second, to demonstrate that social class must be conceptually central to Holocaust analysis, and finally, to contribute to an interdisciplinary discourse on class and gender. By interpreting testimonies at risk of being lost and de-stigmatizing poverty and manual labor, we expose social inequities, and thus can add breadth and depth to our understanding of the Shoah.

\section{Introduction}

Although no definitive statistical data on the socioeconomic background of Holocaust victims is available to date (Hilberg, 1985: 1220; Gerlind, 2005: 5), it can be safely extrapolated that large numbers of Raul Hilberg's estimated 5,100,000 Jewish victims, the vast majority being Eastern European and Polish, belonged to working-class populations. Unable to corroborate my theory with statistics from World War II, I had to rely on secondary sources from the interwar years and primarily on interviews with victims/ survivors on a one-on-one basis, talking about their loved ones, who were murdered by SS Einsatzgruppen (mobile killing squads), in concentration camps, on death marches, or in unknown circumstances. I listened to women's life histories and saw their faces, not abstract numbers. Although the working poor are most likely to represent the majority of Shoah victims, we know very little about their lives. Ordinary people are typically not considered significant for history and are consequently almost entirely absent from the record. The working poor rarely have a public voice (hooks, 2000: 5). Most working-class people in Western societies have virtually no power in public media, and their experiences are negated by the "male, middle-class habit of giving universal or 'historic' significance to an extremely partial experience" (Popular Memory Group, 1982: 210). I have struggled with the relationships between the counter narratives in my study and dominant Shoah representations. The lives of survivors in my study are so different from those widely known, that comparison seems at times almost impossible.

A comparative interpretation was necessary nevertheless, to highlight class differences. Moreover, even private memories of the poor and oppressed are influenced by public discourses. Indeed, the very language any of us speaks is bound up with those discourses. For instance, interviewees were aware of the complex, socially given connotations of the word "survivor," and positioned their own experience in relation to this term. I expanded the definition of "survivor" in my study to include women who fled persecution from 1933 onward. I focused mainly on German and Polish Jews growing up in poverty and 


\section{"You've Never Seen this Kind of Poverty": \\ Facing Class and Gender in Shoah Representations}

working with their hands to earn a living. Along with economic differences I considered variables such as urban versus rural, Western versus Eastern European, age, health, and social networks, affecting whether women perished or survived. In addition to establishing the class-gender connection that is often missing in traditional scholarship, oral history methods highlight the relationship between researcher and narrator and offer a more participatory view into history.

\section{Struggles for Survival}

Understanding the lives of Jews and Gentiles (non-Jews) living in poverty requires that we take into account complexities and power differentials within and across class and gender boundaries. One of my interviewees, Rose Lerman, asserted that the poverty she saw was unimaginable for people who have never experienced it. "You've never seen this kind of poverty" (2001: 179). With these words Lerman responded to my astonishment of the depth of poverty she experienced in interwar Poland. She had just told me about her Gentile Russian neighbors Nadja and Ivan who did not go to school in the winter because they possessed neither shoes nor jackets. She said: "In the house, they wore just rags, and they would sit on top of the stove, keeping themselves warm" (2001: 179). Indeed, I could hardly comprehend this misery. Through the testimonies of concentration camp survivors, the lack of food and clothing is well known. The awesome magnitude of the Shoah, the extremes of suffering and annihilation, have eclipsed analysis of the particular circumstances of working-class and rural poor women and men in the interwar years, and the severe deprivation at that time is not well-documented in scholarship. My exposure to this continuum of survival struggles led me to argue for an inclusion of the interwar years in Holocaust analysis. For example, Lerman's family was poor; however, they owned four hectares of land. Even though this barely sustained them, several times Lerman pointed out that her family was relatively well off compared to the Gentile peasants with whom they were friendly. Nevertheless, she also emphasized that she did not have warm clothes, no coat at all, and wore galoshes instead of shoes in the winter (2001: 262).

Born Rishe Gulkowicz in 1914, Lerman was the tenth, and youngest, child of Orthodox Jewish parents in Dolmatovshchisna, a village in rural Eastern Poland, near Mir, close to the Russian border. Her mother died at age 52, when Lerman was thirteen years old, and she was raised by her older sisters and her father, a blacksmith. Throughout her childhood, Lerman experienced not only antisemitism but also gender discrimination and poverty. At the age of 19, with the help of an older brother, she was able to emigrate to the United States.

In November 1941, Lerman's father, her three sisters, and all of their children were murdered by SS Einsatzgruppen. One brother survived in hiding, and another brother survived three concentration camps. In comparing Lerman's life with that of middle- 


\section{"You've Never Seen this Kind of Poverty": Facing Class and Gender in Shoah Representations}

class survivors, I was struck by the ways her struggle was manifest on a daily basis. Her testimony led me to conclude that many compelling stories of the Shoah may remain, as of yet, undocumented. Therefore, I chose oral history as a base for social analysis and as a scholarly method in order to increase understanding of European history leading up to present day. Life stories allow us to see the social meaning of historical events in terms of the impact on individuals and communities. Lerman's generation of survivors is dying, which makes documentation of their lives urgent.

When I inquired about happy moments she remembered as a child, Lerman recounted:

Hanukkah ${ }^{2}$ was, well, the only good thing about Hanukkah was that they would light candles, and my mother, and then, my sister, when my mother died, they would bake potato pancakes. And that was a big thing and that was a happy time. And we didn't have enough money, my father didn't have enough money for candles, so he would take a potato, cut [it] out in the middle, and put oil and then put in a--some kind of cotton, and that would burn instead of [candles]. . . [C] andles were expensive, and we couldn't afford it. Because they had to do it a whole week, you know. When you think of it, everything was so hard, a little--even a candle. (2001: 20-21)

Lerman's example indicates that access to ritual candles could not be taken for granted in interwar Europe, that they were an unaffordable luxury for poor Jewish families. In a striking parallel, Lerman's narrative resonates with Sybil Milton's description of how women in concentration camps improvised to celebrate the Sabbath:

When Sabbath candles were unavailable they [Orthodox Jewish women from Hungary and Sub Carpathian Ruthenia] blessed electric light bulbs; their colleagues assigned to the Canada barracks at Auschwitz (the barracks where food, clothing, jewelry, and other goods taken from prisoners were stored) filched supplies for them to make Sabbath candles improvised from hollowed-out potato peels filled with margarine and rag wicks. (1984: 314)

Working poor women contributed their collective knowledge and resourcefulness to the spiritual survival of the community, under extremely impoverished camp conditions. Prisoners mobilized and shared survival resources and skills they brought with them from their experiences of poverty before the war. ${ }^{3}$ Yet, their contributions have been rarely acknowledged, illustrating the necessity of problematizing dominant class representations that fail to analyze the Shoah as part of escalating spirals of interwoven oppressions.

\footnotetext{
${ }^{2}$ Hanukkah is a Jewish holiday that lasts eight days and candles are lit every night. In Hebrew, the word "Hanukkah" means "dedication."

${ }^{3}$ I thank Dr. Norma Smith for this insight.
} 


\section{"You've Never Seen this Kind of Poverty": \\ Facing Class and Gender in Shoah Representations}

\section{Voices from the Margins}

In the larger study, from which this is drawn, it was a challenge to locate and interview survivors who both, self-identified as rural or working class and also emigrated to the United States. The United States was a major, often highly desired, destination for Jewish immigrants before, during and after the Shoah. Borrowing Mary Jo Maynes's concept of "worker," I define "ordinary women" as those who came from the milieu of unskilled and skilled manual labor in either industry or agriculture (1995: 8). I include, in my somewhat fluid definition, Jews who worked as independent businesswomen and businessmen, such as self-employed artisans, craftspeople, and salespeople, as this group's work also consisted of manual labor. I compared Polish Jews with German Jews, in both urban and rural environments. Postulating overlapping spirals of victimization, I incorporated the interwar and postwar years (after 1945) into the temporal framework of the Shoah, rather than beginning with the November pogrom ("Kristallnacht") in 1938 and ending with the liberation in 1945. By highlighting gender, class, religious, geographical and temporal variables, I contextualized the escalation and long-term consequences of oppression rather than limiting the impact of the Shoah to a single catastrophic event. Working poor and rural women's life histories provide a broader understanding of the Shoah through the complexity and diversity of their accounts. I chose to interview Jewish women who are simultaneously affected by gender and class difference and whose voices-more than men's voices in general - are all but literally off the record. I explored women's Alltagsgeschichten (day-to-day histories), their struggles for material survival and happiness vis-à-vis poverty, discrimination and resistance based on antisemitism, limits of education, early (thoughts of) emigration and escape, experiences of trauma, death and survival. I found that poverty is a prevalent oppression in numerous life histories of ordinary women and takes much room in their testimonies and consciousness.

\section{Double Jeopardy}

It is important to point out that research on women and the Shoah is relatively young, compared to research on Jews and the Holocaust in general. Early research was rarely conducted with a consideration of gender differences because the premise was that all Jews were subject to Nazis' genocidal politics, regardless of gender. Feminist scholars like Joan Ringelheim began openly questioning this "generic" approach to Holocaust studies in the 1970s and encountered opposition for bringing up the issue of women's invisibility and sexism (1990: 144-45). The first conference on women and the Holocaust in the United States took place in 1983 (Ringelheim, 1985: 741). Feminist Holocaust scholars have shown through complex and nuanced research that although all Jews were threatened with annihilation, gender differences are significant and must not be overlooked. Mary Felstiner states: "Along the stations toward extinction, from arrest through transport to selection, each gender lived its own journey" (1994: 205). Jewish women were oppressed as Jews and as women, as Marion Kaplan has asserted: 


\title{
"You've Never Seen this Kind of Poverty": Facing Class and Gender in Shoah Representations
}

\begin{abstract}
German-Jewish women lived in a position of double jeopardy as a result of their ethnic/religious heritage (which the Nazis would later label "race") and their sex: as Jews and as women they endured discrimination in Germany, and as women they suffered from second-class citizenship in their own Jewish community. (1984: 175)
\end{abstract}

Kaplan problematizes the term 'race' as an ideological construction. Her research focuses on German-Jewish women; however, her statement is also valid for Polish-Jewish women, among others. Concurrent with their victimization as Jews, women were subjected to particular gender/sex-specific experiences, which made them differently vulnerable than men. Those experiences include sexual humiliation, rape, forced prostitution, abortion, and sterilization. Women were specifically targeted for death because they are the givers of life, and because the Nazis considered them inadequate for hard physical labor. As Ringelheim pointed out, women and children often made up 60-70 percent in the death camps' first selections for immediate murder (1990: 348). ${ }^{4}$ In an analogy to Hannah Arendt's famous concept of the banality of evil (1990: 281), Ringelheim identifies the banality of sexism as an undercurrent in the Shoah and Shoah representations (1998: 349). Sexism was-and still is - so ubiquitous that it is likely to be overlooked in critical analyses. Taking gender as difference into account highlights unequal power relationships (Koonz 1987; Bridenthal, Grossmann, and Kaplan, 1984). Myrna Goldenberg discussed women's memories of the Holocaust as "different horrors, same hell" and posits that "the concentration camp was an ultimate expression of the extreme masculinity and misogyny that under-girded Nazi ideology" (1990: 163).

Recent publications underscore the significance of linking the Holocaust and gender (for example, Ofer and Weitzman, 1998; Baer and Goldenberg, 2003; Tec, 2003); however, they fail to emphasize that class was a pivotal factor in death and survival. I propose that contradictory and nuanced effects within social class configurations must be carefully examined. Contrary to typical German middle-class survivors' portrayals of a sudden life change in 1933 with the Nazis' rise to power, struggles with antisemitism and deprivation were daily concerns for working poor families of Poland and Germany before $1933 .{ }^{5}$

\footnotetext{
${ }^{4}$ Ringelheim's research has also shown that more Jewish women than Jewish men were deported. She criticized the Permanent Exhibition at the United States Holocaust Memorial Museum for omitting this fact and other information significant for a more nuanced Holocaust representation. Gendered Holocaust research, Ringelheim demonstrates, is still in danger of being marginalized or absent (1998: 346-350).

${ }^{5}$ Judith Baumel notes that German Jews, who were "an educated and highly literate population" with over fifty percent rescue and survival rates during the Shoah, have left the "largest proportion of documentary evidence for Holocaust researchers" (2000: 33). Andreas Lixl-Purcell provides evidence in his book, based on middle-class women's autobiographies, that many middle-class Jews in Germany in 1933 believed that the Nazi regime would pass quickly (1988). As I have suggested in my study, based primarily on oral history interviews with Jewish women of a wider range of socioeconomic circumstances, there were a considerable number of them to whom this generalization would not apply. For some, the oppression in Germany and Poland seemed so well established and intolerable in the early 1930s that they emigrated in 1934 and 1935.
} 


\section{"You've Never Seen this Kind of Poverty": Facing Class and Gender in Shoah Representations}

All Jews experienced escalating oppression; however, working poor families, with very limited financial resources and personal connections, had barely any chance to escape the genocide. ${ }^{6}$ Ruth Klüger, scholar and middle-class Holocaust survivor from Vienna includes reflections on class, gender, and ethnicity in her autobiography and analysis. She points out that material differences mattered when it came to emigration: "Denn ohne Geld konnte man nicht auswandern. In allen Ländern der Welt waren die armen Juden noch weniger willkommen als die wohlhabenden" ["Because without money one could not emigrate. In all countries of the world, poor Jews were even less welcome than rich Jews"] (1992: 13-14). However, much scholarship does not acknowledge ordinary people for whom life was a daily struggle, even before the Nazi regime. The majority of German-Jewish women whose memoirs are published and archived came from middle-class backgrounds, as Dagmar Lorenz has pointed out (2000:172). Working-class, poor, and rural women seldom had the time and/or resources to write their memoirs. ${ }^{8}$

\section{The Drama of Class}

Facing class does not mean simply adding working-class, poor, and rural women and men to the discourse of the Holocaust but essentially means raising the issue of (male) middleclass bias as a social and an ideological construction and putting a face on missing stories. Privileged classes have constructed ideologies that legitimize not only the economic oppression of the working classes but also their social stigmatization. As bell hooks has pointed out, the Holocaust started with deprivation, not murder (2000: 93).

In her book Feminst Theory: From Margin to Center, hooks criticizes bourgeois class biases in feminist theory, which has been subject to the "hegemonic dominance" of white academic women (1984: 30):

${ }^{6}$ The situation for Polish Jews was especially difficult, see Joseph Marcus, who discusses the different political groups and their leaders' stance vis-à-vis emigration (1983: 390-410). Marcus researched the number of Jewish immigrants to the United States and found that between 1933-39 “429,000 Jews emigrated from Germany, Austria, and Czechoslovakia, which was three times the number from Poland, whereas four times the number of Jews lived in Poland (and in greater distress) than in these three countries combined" (1983: 390). According to Marcus, this disparity existed partly because of unequal immigration quotas but also because of nationalist, racial, and economic considerations (1983: 389).

${ }^{7}$ Translation by Marion Gerlind.

${ }^{8}$ I recognize the originality, importance, and influence of previous feminist scholars' investigations on which my work is based. My study diverges from scholarship that focuses on Jews of the normative (urban) middle class - an unmarked category. Working-class women are almost absent and certainly underrepresented, even in feminist research and analysis. In the preface to her influential work The Making of the Jewish Middle Class [sic] Kaplan notes that she only found "few traces" of GermanJewish working-class women and Eastern European immigrant women in her research: "Memoirs, a rich source for middle-class women's lives, do not exist for their working-class sisters. Working-class women had neither the time nor wherewithal to write memoirs" (1991: xi). Not surprisingly, Kaplan also found less literature about rural Jews than about urban Jews. She identifies this area as one for further research (1991: xi, esp. footnote 11). I am taking this up as a challenge, and my study uncovers life stories from the rich sources of oral testimonies. 


\title{
"You've Never Seen this Kind of Poverty": Facing Class and Gender in Shoah Representations
}

\begin{abstract}
Had poor women set the agenda for feminist movement, they might have decided that class struggles would be a central feminist issue; that poor and privileged women would work to understand class structure and the way it pits women against one another. (1984: 60-61)
\end{abstract}

Thus, she has promoted intellectual work that is, in itself, a feminist praxis (1984: 114) and revolutionary cultural transformation (1984: 163) that encompass the lives and ideas of women and men on the margins. ${ }^{9}$ hooks has also emphasized the importance of accessible language in order to communicate across disciplinary boundaries and beyond academic communities (1988: 77).

Carolyn Steedman argues that working-class autobiography is history on the margins or from the "borderlands" (1987: 22). She stresses the tensions and ambiguities of workingclass life histories vis-à-vis central stories, which they disrupt and counter as a "drama of class" (1987: 22). Working-class subjects are denied emotional complexity and a particular personal history by the dominant culture (1987: 10-11). Steedman says that their lives of lost childhoods, psychological deprivation, and multiple poverties are sad and unwritten stories (1987: 124), and, thus, in her work, she "must make the final gesture of defiance, and refuse to let this be absorbed by the central story" (1987: 144). By applying Steedman's approach to my research in Shoah studies, I found that poverty and survival struggles, intertwined with antisemitism and gender discrimination, run as red threads (Leitmotive) through the lives of working poor Jewish women in East and West, rural and urban environments. Within multiple layers of oppression in their stories, I also discovered resistance, courage, and hope. Personal and community relationships were crucial factors in making oppressive living conditions bearable and often secured women's survival in the face of annihilation.

Ringelheim acknowledges the importance of emphasizing women's strength, agency, friendships, bonding, and care giving in the concentration camps, but also stresses the need to avoid valorizing experiences of oppression: "Oppression does not make people better; oppression makes people oppressed" (1985: 757). She asks: "Is it a methodological and theoretical mistake to look at women and the Holocaust from the vantage point of their

\footnotetext{
${ }^{9}$ Patricia Hill Collins wrote (about Black women): "Knowledge without wisdom is adequate for the powerful, but wisdom is essential to the survival of the subordinate" (2000: 257). She identifies four dimensions of Black feminist epistemology, which are "lived experience as a criterion of meaning, the use of dialogue, the ethic of personal accountability, and the ethic of caring" (266). In other words, in assessing knowledge claims, she interconnects emotion, ethics, and reason (266). Jane Haggis reflected on her experience with academic knowledge claims: "At the most personal level, as someone from a working-class environment and culture, my encounter with university 'knowledge' brought the discovery that working-class people were not 'there' within the academy as participants or subjects but as 'others', as 'ordinary people' to be studied and observed." She continued: "Little space was accorded the commonsense knowledge and logic which I knew operated sensibly to inform the ways in which people conducted their lives. Even less space or recognition was given to the distinct presences and realities of working-class women" (2000: 68).
} 


\section{"You've Never Seen this Kind of Poverty": Facing Class and Gender in Shoah Representations}

difference from men rather than from that of oppression?" (1985: 759). African-American scholars and activists like hooks (1984), Audre Lorde (1984), Barbara Christian (1987), Patricia Hill Collins (2000), and Rose Brewer (1993) have contributed much-needed theorizing of multiple oppressions and have critiqued dichotomous approaches by applying a both/and rather than an either/or approach. In underscoring that interconnectedness, I propose to examine Jewishness, gender, and class differences concurrently.

\section{"I am not ashamed to tell you I was poor"}

Beginning in childhood, ordinary women experienced material, and/or emotional, deprivation as integral to their lives and often prematurely took on adult responsibilities. Many knew that their limited education would overshadow their future; early on, they crafted their personal, as well as their families', survival. Already familiar with multiple oppression, they saw no hope for a better life in Germany or Poland and sought ways to emigrate. Moreover, their struggles did not end with emigration but continued in exile when, for example, making a living as domestic and industrial workers.

Survivors are "coming out" about the stigma of poverty. One example is Fela P. She speaks directly about her class background and the covering up of poverty: "I am not ashamed to tell you I was poor because a lot of people were ashamed to tell -- they were poor but I am not because I am telling the truth" (1997: 1:15:21). She asserts her own position of truthful telling, recognizing that social class is a slippery category that can be hidden or masked. In order to avoid the stigma associated with poverty, Fela indicates that people are willing to construct their narratives in an untruthful way. Her statement hints at much complexity, ambiguity, and contradiction inherent in survivor testimonies. Fela emphasizes poverty because it is a central element of her life and a significant factor in her survival. She is an example of how women mobilized their experience of poverty and antisemitism to escape the Holocaust.

Fela was born in Warsaw in 1922 and described her childhood memories as "not happy" (1997: 1:5:35) because of antisemitism and poverty-her father worked as a sales assistant in a shop. Her Orthodox Jewish parents, Fela, and three siblings shared a two-room apartment with another family. After seven years of public school, Fela could not bear the overt antisemitism any longer. Soon after the beginning of World War II and the bombing of Warsaw, she insisted on accompanying her father on his escape to the Soviet Unionagainst his wishes, for he could not pay for her passage. However, she managed to go with him. Both reached the Russian-occupied part of Poland safely, but Fela decided to return alone to rescue their extended family. Once there, she had to persuade her mother to flee. As their guide, Fela took responsibility for a safe escape-a difficult and dangerous mission during the war. She recounted that her uncle, who left his home to go eastward with them, and was better off than her family, could not cope with the material scarcity in 


\section{"You've Never Seen this Kind of Poverty": \\ Facing Class and Gender in Shoah Representations}

wartime Russian-occupied Poland and returned to Warsaw, where he was killed. Unlike him, Fela and her family members were able to adapt to their even poorer living conditions. Hence Fela's story contradicts the simple inference that diminished monetary resources equaled diminished chances of survival. Her family worked under the Soviet occupation until the German invasion in June 1941. Fela once again guided her family further east out of immediate danger, and everyone survived the war in Kazakhstan. Exiled in the Soviet Union, she worked as a crane operator and, eventually as a bookkeeper and cashier. After the war, her family returned to Poland where they were again confronted by antisemitism. In 1950, she emigrated to Israel.

Escalating antisemitism and the oncoming war motivated Fela to leave everything behind and escape early on, risking further hardship and uprootedness. I interpret her determination to flee, against all odds, and her adaptation to deprivation as survival tools. It can be argued that she did not have much to lose, and, therefore, it was easier for her to leave, but she had to overcome her parents' reluctance and her family's financial limits in order to escape. Her persistence, courage, and resourcefulness under duress are typical of many working poor people who have to stretch limited possibilities for their survival. These stories, compelling for their combination of oppressions, are almost completely absent from the dominant discourse.

\section{Daily Oppressions}

Working poor families have lived with deprivation continuously, as a constant, whereas many middle-class families suffered deprivation for a period of time, under the Nazi regime, and if they survived the Shoah, were likely to return to a semblance of their former lives, all the while maintaining their class identity. I agree with the Popular Memory Group's claim that the choice of subject (individual and/or community) matters in relation to "popular memory" or "dominant memory" and that "'[r]epresentativeness' . . is more likely to be found in popular autobiographical forms where dominant social relations are viewed from the typical subject position: that of daily oppressions and the struggle against them" (1982: 239). In my study, ordinary daily practices like washing laundry and preparing food document class and social differences. Such activities-often seen as marginal and unworthy of further investigation-are motifs running through women's accounts of their experiences before, during, and after the Shoah, and they signify power disparities that shaped these women's lives. We can learn much from knowing who took care of these tasks. Oral histories, like literary ones, are complex cultural products in which private memories and public representations are intertwined (Popular Memory Group, 1982: 241). We need to reflect upon the transformation from history to story, and vice versa, how stories get retold, how and why certain patterns and tropes are established and others omitted. Instead of viewing history primarily through iconic figures and tropes such as Auschwitz survivors and cattle cars, I have highlighted other activities and attitudes, such 


\section{"You've Never Seen this Kind of Poverty": Facing Class and Gender in Shoah Representations}

as housekeeping and, for children, everyday experiences such as envy of another child for having a doll or other prized possession. This was a meaningful way, I found, to recover the life histories of unglamorous/forgotten survivors.

The labor-intensive tasks of everyday life deserve close attention because daily family maintenance played a significant part in collective survival even before 1933. Every member of the family had a role in the fragile fabric of subsistence. Emma Gruenewald, a rural poor German Jew, got up before dawn, milked the goats, made fire in the house, and fetched water from the well. She also helped her mother in raising younger siblings. Similarly industrious from early morning on, Lerman described her eldest sister Elke's daily routine: "[Elke] was such a brave woman. She used to get up at four o'clock in the morning to fire the stove and make food for the family, warm up the house. And, fix stockings. . . . Mend the stockings, because, you know, in poverty, you can't just go buy another pair" (2001: 643).

Lerman remembered her sister from the perspective of a younger sibling. I think that she admired Elke for working very hard and stretching resources, but, at the same time, she did not take her as a role model. Lerman idealized all her sisters, attributing more strength to them than to herself, but she also kept a critical distance. While comparing herself to them (and putting herself down), she elevated her sisters' struggles; however, she also knew that they did not have much choice to change their lives. The fate of her sisters Elke, Libe, and Zlate was life - and death - in poverty, which Lerman was determined to escape. Therefore, her opinion of Elke as a "brave" woman was ambiguous. Lerman praised and admired what Elke was doing, on the one hand, but did not aspire to follow in the footsteps of Elke's difficult life, on the other.

Child labor was commonplace before the Shoah, but it varied widely in extent and necessity. Bertha Alpert, a rural poor Polish Jew, helped her father sell fruit at age eight (Cohen, 1997: 6-7). Paula Meister, a working-class urban Polish Jew, took on her first fulltime job at age thirteen at a furrier's workshop to support her family (2003: 39). Lerman's sister Bunie apprenticed as a seamstress but did household chores during her first year (Lerman, 2001: 199-200). It was not unusual that apprentices had to work as babysitters and maids before their employers taught them professional skills (Glenn, 1990: 27). Adolescents worked in many capacities, such as cooks, babysitters, farmhands or farmers, seamstresses, furriers, domestic workers, saleswomen/vendors, and washerwomen. The more deprived a family was, the more responsibility and work was put on children to ensure the family's survival.

Women have struggled on multiple levels. My narrators experienced gender discrimination and social injustice, such as dowry, constraints on reproductive rights, psychological 


\section{"You've Never Seen this Kind of Poverty": Facing Class and Gender in Shoah Representations}

violence, and sexual abuse and torture. In the interwar years, material hardships often exacerbated the depreciation of women, particularly in larger families with more daughters than sons. Many working poor families could barely if at all follow the custom of providing a dowry for their daughters' marriages, which was a common tradition in many patriarchal European, Middle Eastern, African, and Asian cultures. Working poor families with few resources strained to provide dowries whereas wealthier families could more easily fulfill these financial obligations. The burden fell more heavily on families with girls, while families with boys as recipients of dowry, could benefit from the girls' oppression.

Whereas the interwar years, in general, were a time of much societal transformation with some hopes for change, the Nazi terror regime and the Shoah crushed these hopes. And in conjunction with these social circumstances, there was no doubt that every interviewee in the study was impacted by, and spoke from, her identity as a woman. While remaining aware of historical conditions and class background, I attended to the uniqueness of every woman's voice and experience, but was not seeing individuals necessarily as representative.

Accounts of how the Nazis interrupted and sabotaged children's pursuits of formal education are numerous, and quite typical in representations of the Shoah, in which middleclass survivors are the norm. Readers of Holocaust memoirs seldom learn about children who could not afford to go to high school or private schools. These students' hopes for post-elementary education were usually foreclosed, even before the Nazis blocked the path of formal learning for all Jewish students.

I turn now to two specific topics, laundry and clothing, to highlight social inequality. Lerman's narrative serves as the center story with which I construct my argument of how class differences impacted women's lives.

\section{"[T]he hardest part in our life was washing clothes"}

Laundry was a major ordeal in ordinary women's lives. Publicized testimonies discussing this task and its meanings are rare. It was possibly overlooked because it was not a middle-class activity - done by invisible (working-class) women. I found that laundry stories provide striking insights about social codes and class-consciousness in survivor narratives. Lerman, for example, emphasized the labor intensity of laundry: "That was the hardest part in our life was washing clothes; it was very primitive. We didn't even have a board. . . . You just had to scrub it with your hands. And, the sheets were very heavy, because they were not the fine cotton" (2001: 565-566).

Like Lerman's older sisters, Emma Gruenewald had to help her mother with the laundry every Sunday. Ilse Frank and her mother, German middle-class urban Jews, also had to 


\section{"You've Never Seen this Kind of Poverty": Facing Class and Gender in Shoah Representations}

wash laundry themselves-but only after Jews were prohibited from employing Gentile maids. When mentioned in the narratives of middle-class survivors, doing laundry themselves was an exceptional circumstance. Mathilda Stein, a middle-class and rural Jew from Germany, watched her mother and the maid washing clothes:

Laundry--the wash house was on the other side of the stables. That is very hard work you know--. . . . She [Stein's mother] was busy, busy, I mean you didn't do laundry too often; you did laundry maybe once a month. Also, if you did it too often it betokened that you didn't have enough linens.” (2002: 29)

Stein recalled its social significance-affluence was measured by the frequency of washing laundry. Doing laundry "too often" was a sign of poverty, as Stein asserted: "Right, [that] you were poor. So you didn't do that" (2002: 29). Laundry symbolizes the drudgery of life, and points to power differentials. There were nine children in Lerman's family, as compared to two in Stein's. The unpleasant task at hand was the same for all families, but the amount of laundry in larger families made more frequent washings necessary. Even more pressed than Lerman's family were the Gruenewalds because they washed their laundry every week. Also, the quality and weight of the clothing made a difference. Linen of lesser quality was usually heavier, or "rough," in Lerman's words. Lines of demarcation along laundry and employment of servants can certainly mark gender and, generally, class distinctions, but they are sometimes fluid and unstable. For example, Bertha Alpert's mother, who was working poor and had nine children, hired a woman to do the washing and cleaning. Ordinary women's lives were filled with work, and their workloads also varied in difficulty and degree, depending on factors such as family size, and economic background.

\section{"I could see how she was dressed. You could tell a poor child."}

Another signifier for social class standing is clothing, which middle-class accounts rarely problematize. Outward appearance is one indicator of societal status, gender, and religion/ethnicity. Roman Vishniac, in A Vanished World, photographed poor Jews, which was unusual for the time-poverty that partly manifested in clothing and a lack thereof. The subject of clothing often came up in my study and deserves scrutiny. I did not fully understand its significance until interview participants pointed it out to me. When I asked Sabina Zimering, a middle-class Polish survivor, how she knew that her classmate Fela Sauer was poor, she responded: "I could see how she was dressed. You could tell a poor child" (2002: 59). Zimering recalled "a lot of poverty" in Piotrkow and in Sauer's home specifically: "Her mother was a widow; there were two daughters. And I remember whenever I went to her house it was shocking how poor they were. Her clothes . . . were worse than anybody else['s]"(2002: 23). Zimering believes that Fela Sauer perished in Treblinka. Her life story would be completely lost had Zimering not talked about her 


\section{"You've Never Seen this Kind of Poverty": \\ Facing Class and Gender in Shoah Representations}

during our interview.

Previously, Lerman had told me the story behind her own family photo, which was taken when she was about six years old. I was surprised to learn of the magnitude of this photographic ordeal for a rural poor family:

RL: [W] never had a picture of my--none of my grandparents, we have a picture, or, even of my aunt that I loved so much, because picture taking was a very big--you had to go to Mir, and it was expensive. So, finally, my sister Sarah, from Chicago, asked very much--she was very lonely for us-that we should send her one. So, my father took all of us and we went to take a picture. ... I have to show it to you. So, they took pictures, mainly for Sarah. But, it was such a big production, you know, you have to take a horse and buggy and take it, and it's expensive. And, I didn't even have a nice dress, so the photographer's daughter was my age, and they lent me a dress for the photo, and I remember that the girl was very angry. She thought I was going to take it or something, you know, but just for that moment, which was so silly. And, they were ashamed because, you know, I didn't have a nice little dress. And, I will never forget it; she was very angry why they lent me

MG: What did you have on before the dress? . .

RL: Well, whatever there was; you know. It wasn't very much. We were poor. We had to have--if it was torn, we had to fix it, you know. Don't forget, ten children is--. (2001: 45-46)

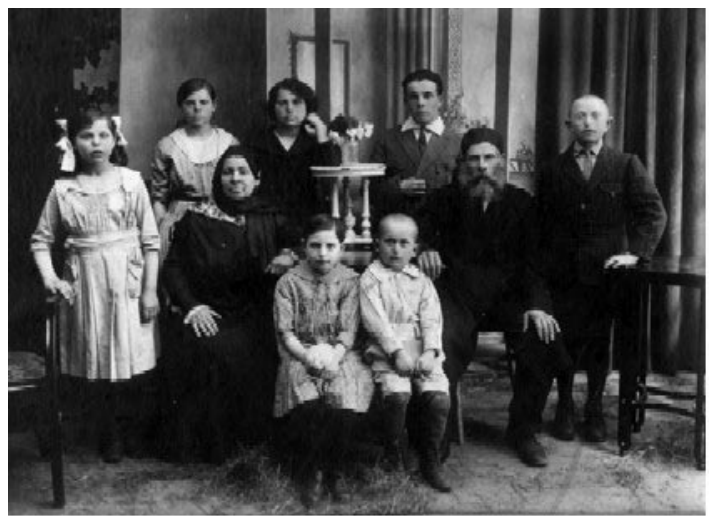

Gulkowicz family, ca. 1921. Left to right (standing) Bunie, Zlate, Libe, Avrohom (Eddy), Sholem. Left to right (seated) Peshe (mother), Rishe (Rose), Itchoek, Benjamin (father). Absent: Sarah (in USA), Elke. Photograph courtesy of Rose Lerman. 


\section{"You've Never Seen this Kind of Poverty": Facing Class and Gender in Shoah Representations}

I think that, although Lerman was not especially attached to the possession of garments, she acknowledged that clothes were assets, and their loss caused grief, as she recalled in continuing the story of the family photo:

You know, Marion, everything had so much meaning. A dress for a child that they had to borrow. And, you can imagine the poverty. . . I think I told you, this is the suit--this is the suit that was borrowed from my cousin [for the family photo], and it was lost. And, a pair of warm shoes that my sister Sarah sent for my mother. And, it was wintertime, and it fell out while they were traveling. And, I remember it was such a tragedy. You wouldn't believe it, how upset--we were crying, because the suit belonged to my cousin, and the shoes that my sister sent especially for my mother. They were brand new, and they were lost. Because, it was in the snow, and we--the wagon was very loose, and so it just fell off. The package fell down. And then, they went to look for it in the middle of the night.(2001: 175-177)

Lerman's family could not recover the package and paid a high price for this photo. Photographs record a family's history, and no one wanted to look poor. Most poor people could not afford to have their pictures taken in the first place. Only the wealthy could easily document their lives through photography. Absence in pictures is the visual equivalent of absence in the dominant scholarly discourse. ${ }^{10}$ Ordinary people become both literally and symbolically invisible.

\section{Conclusion}

I find it crucial to uncover, foreground, and create diverse texts, including oral histories, as counterpoint to dominant cultural representations. This is a prerequisite for a socially balanced historical memory. At the same time, I assert, paradoxically, that working-class histories record dramas outside and inside the common parameters-as histories from the borderlands (Steedman). Women (and men) have manipulated gender conventions and acted subversively in many ways. For instance, by marrying her brother who had taken another surname in exile, Lerman circumvented immigration restrictions and escaped Poland.

Focusing on the ordinariness of life, I strive to contribute to a better understanding of working-class and rural poor women's life histories, including their subversiveness and difference. Their lives are webs of tension, spanning the commonplace and the unique. I call into question claims for privileging literary accounts by listening to the wisdom expressed in oral testimonies. Narratives by working-class and rural poor women deepen and broaden our understanding of history. By including silenced voices in the framework of the Shoah, established, yet unstable, historical representations are challenged. Oral history is a method of sharing experiences on a level that contributes to our understanding

\footnotetext{
${ }^{10}$ I thank JB for pointing this comparison out to me.
} 
of collective as well as individual history. It holds the potential to empower people through their own words and worlds (Popular Memory Group, 1982: 223) and can contribute to a socialist history and socialist analysis. I acknowledge the "centrality of storytelling to working-class accounts of social reality" (Popular Memory Group, 1982: 229). Mindful interaction between interviewer and interviewee can decrease the risk of objectifying life histories and open gates to cross-generational, cross-cultural, and transnational dialogues.

Literary accounts have told us primarily of middle class lives, which have become models for the understanding of Jewish families in general. Academics and activists struggling for social justice must challenge middle-class and gender biases. At times, poverty reduced survival because of limited resources and at other times people survived through resources developed in poverty. My research brings to the fore the complexities of class, gender, Jewishness, personality, and family culture in experience of oppression and of survival.

I propose that social meanings of ordinary daily practices be evaluated in terms of class analysis. Often disregarded or seen as unworthy of investigation, they are red threads running through people's lives, signifying power differentials. In many Jewish survivor narratives, ordinary women are portrayed as maintaining dignity in the face of deprivation and despair. As Celia Heller suggested, their everyday survival, even before the Holocaust, can be interpreted as a form of resistance (1977: 250). By examining life activities like doing laundry or clothing one's family, we get a view into lived history that allows us to understand the social meaning of women's (and men's) experiences and behavior. This kind of analysis transforms scholarship into a people's history. Analyzing class differences and poverty in terms of oppression complicates the discussion not only of women and the Shoah but reshapes the broader spectrum of gender, historical, sociological, ethnic, and cultural studies as well. 


\section{"You've Never Seen this Kind of Poverty": \\ Facing Class and Gender in Shoah Representations}

\section{REFERENCES}

Alpert, Bertha, see Cohen, Andrew.

Arendt, Hannah. 1990. "Postcript to Eichmann in Jerusalem." In Thinking the Unthinkable: Meanings of the Holocaust. Roger S. Gottlieb (ed.). Nahwah, NJ: Paulist Press, pp. 277-290.

Baer, Elizabeth R., and Myrna Goldenberg, eds. 2003. Experience and Expression: Women, the Nazis, and the Holocaust. Detroit: Wayne State University Press.

Baumel, Judith Tydor. 2000. "'You Said the Words You Wanted Me to Hear but I Heard the Words You Couldn't Bring Yourself to Say': Women's First Person Accounts of the Holocaust." Oral History Review, Vol. 27, No. 1, pp. 17-56.

Brewer, Rose M. 1993. "Theorizing Race, Class and Gender: The New Scholarship of Black Feminist Intellectuals and Black Women's Labor." In Theorizing Black Feminisms: The Visionary Pragmatism of Black Women. Stanlie M. James and Abena P.A. Busia (eds.). London: Routledge, pp. 13-30.

Bridenthal, Renate, Atina Grossmann, and Marion Kaplan, eds. 1984. When Biology Became Destiny: Women in Weimar and Nazi Germany. New York: Monthly Review Press.

Christian, Barbara. 1987. “The Race for Theory.” Cultural Critique, Vol. 6, pp. 51-63.

Cohen, Andrew D. 1997. "A Tribute to Bertha Berger Alpert: The Story of Bertha Berger Alpert's life.” Minneapolis, MN. Unpublished Monograph.

Collins, Patricia Hill. 2000. Black Feminist Thought: Knowledge, Consciousness and the Politics of Empowerment. New York: Routledge.

Felstiner, Mary Lowenthal. 1994. To Paint Her Life: Charlotte Salomon in the Nazi Era. New York: Harper Collins.

Frank, Ilse Prager. 2001. "Thankful to Have a Life after Nazi Germany.” Interview with Marion Gerlind. Union, NJ. Unpublished Manuscript.

Gerlind, Marion. 2005. Off the Record: Remapping Shoah Representations from Perspectives of Ordinary Jewish Women. Dissertation: University of Minnesota. UMI 3192016. 
Glenn, Susan A. 1990. Daughters of the Shtetl: Life and Labor in the Immigrant Generation. Ithaca: Cornell University Press.

Goldenberg, Myrna. 1990. "Different Horrors, Same Hell. Women Remembering the Holocaust." In Thinking the Unthinkable: Meanings of the Holocaust. Roger S. Gottlieb (ed.). Nahwah, NJ: Paulist Press, pp. 150-166.

Gruenewald, Simon. N.d. “Tante Emma: Lebensbild einer Dorfjüdin”. Leo Baeck Institute, Max Gruenewald Collection, New York City. Unpublished Manuscript.

Haggis, Jane. 1990. "The Feminist Research Process - Defining a Topic.” In Feminist Praxis: Research, Theory and Epistemology in Feminist Sociology. Liz Stanley (ed.). London: Routledge, pp. 67-79.

Heller, Celia S. 1977. On the Edge of Destruction: Jews of Poland between the Two World Wars. New York: Columbia University Press.

Hilberg, Raul. 1985. The Destruction of the European Jews. New York: Holmes and Meier.

hooks, bell. 2000. Where We Stand: Class Matters. New York: Routledge.

hooks, bell. 1988. "Keeping Close to Home: Class and Education.” In Talking Back: Thinking Feminist, Thinking Black. Boston: South End, pp. 73-83.

hooks, bell. 1984. Feminist Theory: From Margin to Center. Boston: South End.

Kaplan, Marion A. 1991. The Making of the Jewish Middle Class: Women, Family, and Identity in Imperial Germany. New York: Oxford University Press.

Kaplan, Marion A. 1984. "Sisterhood under Siege: Feminism and Anti-Semitism in Germany, 1904-1938." In When Biology Became Destiny: Women in Weimar and Nazi Germany. Renate Bridenthal, Atina Grossmann, and Marion Kaplan (eds.). New York: Monthly Review Press, pp. 174-196.

Klüger, Ruth. 1992. Weiter Leben: Eine Jugend. Göttingen: Wallstein Verlag.

Koonz, Claudia. 1987. Mothers in the Fatherland: Women, the Family and Nazi Politics. New York: St. Martin's. 


\section{"You've Never Seen this Kind of Poverty": Facing Class and Gender in Shoah Representations}

Lerman, Rose. 2001. "Hoping For A Better World." Interview with Marion Gerlind. Transcription by Lynn Deines and Marion Gerlind. Berkeley, CA. Unpublished Manuscript.

Lixl-Purcell, Andreas, ed. 1988. Women of Exile: German-Jewish Autobiographies since 1933. Westport, CT: Greenwood.

Lorde, Audre. 1984. Sister Outsider: Essays and Speeches. Freedom, CA: The Crossing Press.

Lorenz, Dagmar C.G. 2000. "The Interchange between Experience and Literature: German-Jewish Women Writers of the Holocaust." In Facing Fascism and Confronting the Past: German Women Writers from Weimar to the Present. Elke P. Frederiksen, and Martha Kaarsberg Wallach (eds.). New York: State University of New York Press, pp.171-185.

Marcus, Joseph. 1983. Social and Political History of the Jews in Poland, 1919-1939. Berlin: Mouton Publishers.

Maynes, Mary Jo. 1995. Taking the Hard Road: Life Course in French and German Workers' Autobiographies in the Era of Industrialization. Chapel Hill: University of North Carolina Press.

Meister, Paula. 2003. Interview with Marion Gerlind. Minnetonka, MN. Unpublished Manuscript.

Milton, Sybil. 1984. "Women and the Holocaust: The Case of German and German-Jewish Women.” In When Biology Became Destiny: Women in Weimar and Nazi Germany. Renate Bridenthal, Atina Grossmann and Marion Kaplan (eds.). New York: Monthly Review Press, pp. 297-333.

Ofer, Dalia, and Lenore Weitzman, eds. 1998. Women in the Holocaust. New Haven: Yale University Press.

P., Fela. 1997. Interview by Survivors of the Shoah Visual History Foundation, Melbourne, Australia, July 2. Interview Code 33606. Videotapes. Unpublished.

Popular Memory Group. 1982. "Popular Memory: Theory, Politics, Method.” In Making Histories: Studies in History-Writing and Politics. Richard Johnson, Gregor McLennan, Bill Schwarz, and David Sutton (eds.). University of Birmingham: Centre for Contemporary Cultural Studies, pp. 205-252. 
Ringelheim, Joan. 1998. "The Split between Gender and the Holocaust." In: Women in the Holocaust. Dalia Ofer and Lenore Weitzman (eds.). New Haven: Yale University Press, pp. 340-350.

Ringelheim, Joan. 1990. "Thoughts About Women and the Holocaust." In Thinking the Unthinkable: Meanings of the Holocaust. Roger S. Gottlieb (ed.). Nahwah, NJ: Paulist Press, pp. 141-149.

Ringelheim, Joan. 1985. "Women and the Holocaust: a Reconsideration of Research." In Signs: Journal of Women in Culture and Society, Vol. 10, No. 4, pp. 741-761.

Steedman, Carolyn Kay. 1987. Landscape for a Good Woman: A Story of Two Lives. New Brunswick, NJ: Rutgers University Press.

Stein, Mathilda Wertheim. 2002. "Testimony of an Eye Witness in Hessen, 1920-34." Interview with Marion Gerlind. Atlanta, GA. Unpublished Manuscript.

Tec, Nechama. 2003. Resilience and Courage: Women, Men, and the Holocaust. New Haven: Yale University Press.

Vishniak, Roman. 1983. A Vanished World. 1st ed. New York: Farrar, Straus \& Giroux.

Zimering, Sabina S. 2002. "Hiding in the Open." Interview with Marion Gerlind. Minneapolis, MN. Unpublished Manuscript. 